\title{
A Mutation Inhibiting Protoplasmic Incompatibility in Podospora anserina that Suppresses an Extracellular Laccase and Protoperithecium Formation
}

\author{
By J. LABARÈRE AND J. BERNET \\ Laboratoire de Génétique, allée des Facultés, 33405 Talence, France
}

(Received 17 May 1978)

\section{INTRODUCTION}

In Podospora anserina, protoplasmic incompatibility due to non-allelic gene interaction involves the genes of nine loci (Delettre \& Bernet, 1976). Biochemical investigations, which were possible on the $R / V$ interaction because of its temperature dependence, have shown that cell destruction is associated with the appearance of three enzyme activities absent in normal cells: a phenoloxidase (laccase III), and two proteolytic enzymes (proteases III and IV) thought to be responsible for cell lysis (Bégueret \& Bernet, 1973).

In the present paper, we show that a mutation in gene $\bmod C$, selected for the suppression of cell destruction, resulting from the $R / V$ interaction (Labarère \& Bernet, 1977), also inhibited formation of the three associated enzyme activities.

\section{METHODS}

Organism, strains and culture conditions. These have been described previously (Esser, 1974). The cross $q r V \times \hat{O} R V I$ was the source of the thermosensitive self-lysing strain $R V$ combining the incompatibility genes $R$ and $V$. At $32{ }^{\circ} \mathrm{C}$, this strain grows normally, but exposure to $26^{\circ} \mathrm{C}$, at which temperature the $R / V$ interaction starts, results in cell destruction (Labarère, 1973). The heterokaryotic strain $\bmod C^{+}+\bmod C$ was formed from homokaryotic plus strains, forced by non-allelic riboflavin-requiring mutations and fertilized by pouring a suspension of microconidia from a strain of the opposite mating type.

Preparation of cell-free extracts, chromatographic procedures, proteolytic activity and phenoloxidase (laccase) measurements. These procedures have been described previously (Boucherie et al., 1976).

Drugs. Protease inhibitors, phenylmethylsulphonyl fluoride (PMSF) and ovomucoid were purchased from Sigma.

\section{RESULTS AND DISCUSSION}

The same three proteolytic enzymes were found in cell extracts-of a normal strain and of $R V$ strains grown at $32^{\circ} \mathrm{C}$ (Boucherie et al., 1976): the first two eluted ( $\mathrm{NaCl}$ gradient on a DEAE-cellulose column) were basic enzymes (proteases A and B), sensitive to PMSF and ovomucoid; the third (protease ${ }_{*}^{-C}$ ) was an acidic enzyme showing complete resistance to both inhibitors. When proteases were investigated in an $R V \bmod C(I)$ strain cultured at $32{ }^{\circ} \mathrm{C}$, the elution profile again showed that proteolytic activity was distributed between three fractions (Fig. 1). Subsequent separation on Sephadex G-100 showed that these three enzyme activities, were identical to"proteases A, B and C. Thus, the mod $C(l)$ mutation had no effect on the proteases present in normal cells.

Previously, proteolytic activity in an $R V$ strain cultured at $32{ }^{\circ} \mathrm{C}$ and shifted for $10 \mathrm{~h}$ to $26{ }^{\circ} \mathrm{C}$ was found to be distributed between four fractions (Bégueret \& Bernet, 1973): the first two proteases eluted were proteases A and B; the later two were novel acid proteolytic enzymes (proteases III and IV) that were sensitive to PMSF and ovomucoid. However, when the $R V$ strain carried the $\bmod C(l)$ mutation, the proteolytic activity elution profile was not 


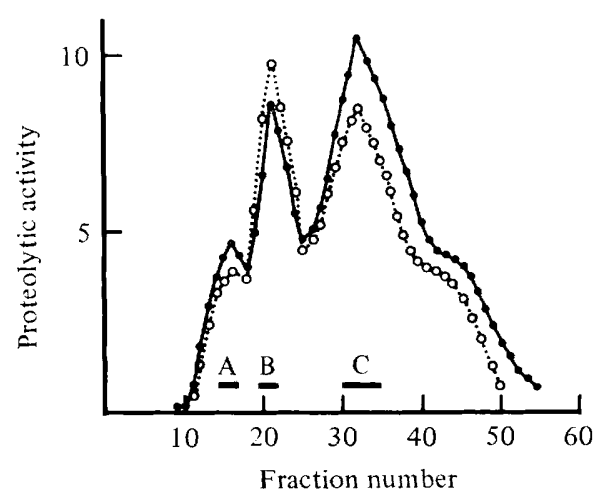

Fig. 1. Elution profile from DEAE-cellulose of the proteolytic enzymes of strain $R V \bmod C(l)$ after $3 \mathrm{~d}$ culture at $32{ }^{\circ} \mathrm{C}(\bullet)$ and after $3 \mathrm{~d}$ culture at $32{ }^{\circ} \mathrm{C}$ plus $15 \mathrm{~h}$ exposure to $26^{\circ} \mathrm{C}(0)$. The fractions pooled for further chromatography on Sephadex G-100 are indicated.

significantly modified by $15 \mathrm{~h}$ exposure to $26^{\circ} \mathrm{C}$ (Fig. 1). Investigations of the third activity eluted revealed similarities with protease $C$ : an apparent molecular weight of 40000 to 42000, complete resistance to PMSF and ovomucoid and an identical pH dependence curve. $\operatorname{Mod} C(I)$ is thus the second example of a mutation (Boucherie et al., 1976) which suppresses both cell lysis and its two associated specific proteases.

The $R / V$ interaction also resulted in the presence in cell extracts of laccase III (Boucherie et al., 1976). This enzyme activity was not found in an $R V \bmod C(l)$ strain, either when the strain was grown continuously at $32{ }^{\circ} \mathrm{C}$ or after $24 \mathrm{~h}$ exposure to $26^{\circ} \mathrm{C}$. In contrast to proteases III and IV, the laccase was found in normal strains, but it was present exclusively as an extracellular enzyme activity (Boucherie \& Bernet, 1977). In the mutant strain modC(1), laccase III was never found, either in cell extracts or in the culture filtrates. Thus the modC $(I)$ mutation suppresses laccase III both in its extracellular (or normal) and intracellular (or pathological) forms.

Preliminary investigations on three independent $\bmod C$ mutations showed that they resulted in defects in the formation of protoperithecia (Labarère \& Bernet, 1977). The mutant strain modC $(I)$, for instance, was completely devoid of protoperithecia. To see if this mutant trait exhibited an autonomous expression, we examined the heterokaryotic strain $\bmod C^{+}+\bmod C(1)$, forced by auxotrophic mutations. To the wild-type nucleus, the incompatibility gene $e(A)$ was added. Because of its interaction with the $c(s)$ gene, the presence of the $e(A)$ gene reduces the fertility rate in the cross $Q e(A) \times \delta c(s)$ to $2 \times 10^{-4}$ when compared with that of the control crosses $c(s) \times c(s)$ or $e(A) \times e(A)$. As expected, because of the recessiveness of the $\bmod C(I)$ mutation, the heterokaryotic strain $e(A) \bmod C^{+}+\bmod C(I)$ produced protoperithecia at a normal density $\left(20\right.$ per $\left.\mathrm{mm}^{2}\right)$. When $c(s)$ microconidia were poured on the heterokaryon cultures, the fertility rate was $2 \times 10^{-4}$, i.e. that found for the homokaryotic $e(A)$ cultures. Since the reaction preventing $\& e(A) \times \hat{\sigma} c(s)$ hybridizations developed between the trichogyne $e(A)$ and the microconidia $c(s)$ (Esser, 1959; Bernet, 1965), it can be deduced that in the heterokaryotic strain $\bmod C^{+}+\bmod C(l)$, no compatible $\bmod C(l)$ trichogyne (or protoperithecium) was formed. Investigations of the progeny of the rare perithecia that developed (about 100 were examined) showed that they arose from $e(A)$ $\bmod C^{+}$oogonia. Similar results were also obtained with a second mutation $\bmod C(2)$ that resulted in the formation of abnormal protoperithecia which never developed into perithecia. In the heterokaryotic strain $\bmod C^{+}+\bmod C(2)$, none of the fruiting bodies derived from the female $\bmod C(2)$ nucleus. Thus, from these experiments, we deduce that $\bmod C^{+}$expression is needed for normal protoperithecium formation since the modC genetic block was not relieved by its presence in a common cytoplasm with the wild-type gene $\bmod C^{+}$. 
In conclusion, the $\bmod C$ mutation which abolishes cell lysis induced by the $R / V$ interaction also prevents the formation of its associated specific enzymes. In addition, like bacterial mutations that pleiotropically inhibit exoenzymes and specific morphogenetic processes (Ayusawa et al., 1975; Kunst et al., 1974), the modC(1) mutation per se not only suppresses laccase III, an extracellular activity, but also abolishes protoperithecium formation.

\section{REFERENCES}

Ayusawa, D., Yoneda, Y., Yamane, K. \& Maruo, B. (1975). Pleiotropic phenomena in autolytic enzyme(s) content, flagellation and simultaneous hyperproduction of extracellular $\alpha$-amylase and protease in a Bacillus subtilis mutant. Journal of Bacteriology 124, 459-469.

Bégueret, J. \& Bernet, J. (1973). Proteolytic enzymes and protoplasmic incompatibility in the fungus Podospora anserina. Nature New Biology 243, 94-96.

BERNET, J. (1965). Mode d'action des gènes de barrage et relation entre l'incompatibilité cellulaire et l'incompatibilité sexuelle chez le Podospora anserina. Annales des sciences naturelles: Botanique 6, 611-768.

BOUCHERIE, H. \& BERNET, J. (1977). Intracellular and extracellular phenoloxidases in the fungus Podospora anserina. Effect of a constitutive mutation in a gene involved in their posttranscriptional control. Molecular and General Genetics 157, 53-59.

Boucherie, H., Bégueret, J. \& Bernet, J. (1976). The molecular mechanism of protoplasmic incompatibility and its relationship to the formation of protoperithecia in Podospora anserina. Journal of General Microbiology 92, 59-66.

DeletTre, Y. M. \& Bernet, J. (1976). Regulation of proteolytic enzymes in Podospora anserina: selection and properties of self-lysing mutant strains. Molecular and General Genetics 144, 191-197.

ESSER, K. (1959). Incompatibilitätsbeziehungen zwischen geographischen Rassen von Podospora anserina. III. Untersuchungen zur Genphysiologie der Barrage-Bildung und Semi-Incompatibilität. Zeitschrift für Vererbungslehre 90, 445-456.

ESSER, K. (1974). Podospora anserina. In Handbook of Genetics, vol. 1, pp. 531-551. Edited by R. King. New York and London: Plenum Press.

Kunst, F., Pascal, M., Lepesant-Kejlarova, J., Lepesant, J., Billaut, A. \& Dedonder, R. (1974). Pleiotropic mutations affecting sporulation conditions and the synthesis of extracellular enzymes in Bacillus subtilis. Biochimie 56, 1481-1489.

LABARÈre, J. (1973). Propriétés d'un système d'incompatibilité et intérêt de ce système pour l'étude de l'incompatibilité. Comptes rendus hebdomadaires des séances de l'Académie des sciences 276, 1301-1304.

Labarère, J. \& Bernet, J. (1977). Protoplasmic incompatibility and cell lysis in Podospora anserina. I. Genetic investigations on mutations of a novel modifier gene that suppresses cell destruction. Genetics 87, 249-257. 